\title{
Study on Improving the Durability of Cement Concrete for Bridge Mixing With Nano Material by Experiment
}

\author{
Ling Sun ${ }^{1,}$, Li Wang ${ }^{1, b}$, Yanjun Chen ${ }^{2, ~ c}$, Xuyuan Liang ${ }^{2}$ and Wenyong Yu ${ }^{1}$, \\ Yan Wang ${ }^{2}$ \\ 1 Heilongjiang institute of technology, China \\ 2 Longjian Road And Bridge Company Limited, China \\ a 532734185@qq.com, b 691869360@qq.com, c1556439202@qq.com
}

\begin{abstract}
Keywords: cement concrete; fly-ash; Nano-SiO ${ }_{2}$; Durability,
Abstract. In the essay, that cement concrete mixed with $\mathrm{Nano}_{-} \mathrm{SiO}_{2}$, the cement concrete mixing with Nano scale fly-ash and the cement concrete mixing with $\mathrm{Nano}_{-} \mathrm{SiO}_{2}$ have been tested on preventing the adverse effect of sulfates shows that the cement concrete mixing with $\mathrm{Nano}-\mathrm{SiO}_{2}$ improves the performance of the concrete to prevent the adverse effect of sulfates.
\end{abstract}

\section{Introduction}

As bridges are located in different areas, concrete bridges will be subjected by vary damage acting, such as acts by freezing and thawing and the wetting and drying, and eroding of some chemical substances and wearing the change in temperature and mechanical acting.

Under such bad environment, the concrete of bridge used will be subjected by eroding of some substances for a long time, will be inevitably leading to deterioration of its structural performance, less durability, as well under the combined action of driving load, the bridge will lead to damage ahead of the time.

Chemical corrosion to cementitious materials in concrete includes soft water erosion, salt (sulfate, magnesium) corrosion, acid corrosion and corrosion of alkali etc., the most destruction to it is the erosion of sulfate corrosion ${ }^{[1]}$.

The permeability and pore structure of concrete is one of the main factors that affect the durability of concrete. Generally, the more permeability of the concrete, the more anti-corrosion to the concrete and if there are more pores in concrete, the sulfate attack is more serious; less pores, anti-corrosion is good.

The main mineral components of cement clinker are Alite $\left(\mathrm{C}_{3} S\right)$, Belite $\left(\mathrm{C}_{2} \mathrm{~S}\right)$, Tricalcium aluminate $\left(\mathrm{C}_{3} \mathrm{~A}\right)$ and Brownmillerite $\left(\mathrm{C}_{4} \mathrm{AF}\right)$. The degree of sulfate corrosion of concrete is affected by the different compositions of concrete and subjected by the impact of external environmental conditions as well. There is more Alite $\left(\mathrm{C}_{3} \mathrm{~S}\right)$ and Tricalcium aluminate $\left(\mathrm{C}_{3} \mathrm{~A}\right)$ in cement, the cement will act with sulfate existed in environment, the resulted calcium sulfate will act with the solid-state Tricalcium aluminate hydrated in concrete and ettringite will be produced. The volume of ettringite produced in concrete will expand more than 50 percent of itself. There is swelling stress in hardened cement stone, it will cause great damage in concrete and cement stone will tend to corrosion.

Nano material with small sides of particle and large specific surface area, the characteristics of it, such as surface effect, volume effect, size effect, and macroscopic quantum tunneling effect, are different from traditional materials, different physical and chemical characteristics are showed ${ }^{[2]}$. This essay showed that the capability of anti-sulfate in concrete will be studied on concrete mixed with fly ash and nano $\mathrm{SiO}_{2}$.

\section{Raw Materials for Testing}

Cement: 42.5 Portland cement produced by Harbin Tian E Cement Manufactured Workshop, its compressive stress and flexural stress for three days are $27.6 \mathrm{MPa} 、 4.8 \mathrm{MPa}$; and its compressive 
stress and flexural stress for 28 days are $48.9 \mathrm{MPa} 、 7.8 \mathrm{MPa}$. its basic chemical compositions are showed in table 1.

Table 1 42.5 PO Cement Basic Chemical Compositions Showed in the Table

\begin{tabular}{c|c|c|c|c|c|c|c|c|c}
\hline $\begin{array}{c}\text { Chemical } \\
\text { Composition }\end{array}$ & $\mathrm{SiO}_{2}$ & $\mathrm{Fe}_{2} \mathrm{O}_{3}$ & $\mathrm{Al}_{2} \mathrm{O}_{3}$ & $\mathrm{CaO}$ & $\mathrm{MgO}$ & $\mathrm{K}_{2} \mathrm{O}$ & $\mathrm{Na}_{2} \mathrm{O}$ & $\mathrm{SO}_{3}$ & $\begin{array}{c}\text { Loss of } \\
\text { Ignition }\end{array}$ \\
\hline & 22.12 & 5.42 & 4.32 & 63.18 & 0.99 & - & - & 2.20 & 1.00 \\
\hline
\end{tabular}

Fly ash: it comes from ground residue of Harbin Hulan the third power plant's coal powder burned. The basic components are $\mathrm{SiO}_{2}, \mathrm{Al}_{2} \mathrm{O}_{3}$, and $\mathrm{Fe}_{2} \mathrm{O}_{3}$, the total content of these three components is more than 70 percent, the more of it, Chemical composition and physical and mechanical indexes showed in table2.

Table2 Contents of Fly Ash

\begin{tabular}{c|c|c|c|c|c|c}
\hline $\begin{array}{c}\text { Chemical } \\
\text { Composition }\end{array}$ & $\mathrm{SiO}_{2}$ & $\mathrm{Al}_{2} \mathrm{O}_{3}$ & $\mathrm{Fe}_{2} \mathrm{O}_{3}$ & $\mathrm{CaO}$ & $\mathrm{MgO}$ & $\begin{array}{c}\text { Loss of } \\
\text { Ignition }\end{array}$ \\
\hline Contents (\%) & 50.96 & 25.21 & 9.2 & 3.7 & 1.13 & 5.74 \\
\hline
\end{tabular}

Nona $\mathrm{SiO}_{2}$ : manufactured by Beijing NaChen Science and Technology development Co., Ltd. Its index: OD is 30nm, Purity is more than 99.9 percent. For discussion, in the essay nona- $\mathrm{SiO}_{2}$ is instead of NS.

Sand: the sand is medium sand of fineness modulus 2.7, meets the II region grading requirements. Under 《Technical specification for construction of highway bridges and culverts》(JTG/ F50-2011). stones: $5 \mathrm{~mm} \sim 31.5 \mathrm{~mm}$ crushed stones, the crushing value is 7.8 percent, better shape of grain, continuous grading, meet specification of (JTG /F50-2011)

\section{Test Method}

3.1 The Mix. According to method of regulation of 《Standard Test Method for long term performance and durability of ordinary concrete》 (GB/T50082-2009), the sides of the cubic specimens is $100 \mathrm{~mm} \times 100 \mathrm{~mm} \times 100 \mathrm{~mm}$, the characteristic of the concrete is C30. The content of fly ash is 15 percent. In contrast with this, there is another Portland cement concrete without fly ash. With the contrast testing, the capability of concrete with NS to anti-corrosion is analyzed. NS and fly ash are in place with identity of cement, admixture is one percent of cementitious material. The total of cementitious is $390 \mathrm{~kg} / \mathrm{m}^{3}$, the rate sand is 34 percent, the volume of water is fixed at $185 \mathrm{~kg} / \mathrm{m} 3$, the mix is showed in table 3 .

Table 3 The Mixes of The Specimen For Sulfate Corrosion Testing

\begin{tabular}{|c|c|c|c|}
\hline No. & Cement & Fly Ash & Nano-SiO $_{2}$ \\
\hline L-1 & 100 & & \\
\hline L-2 & 80.0 & 20.0 & 0 \\
\hline L-3 & 79.5 & 20.0 & 0.5 \\
\hline L-4 & 79.0 & 20.0 & 1.0 \\
\hline L-5 & 78.0 & 20.0 & 2.0 \\
\hline L-6 & 77.0 & 20.0 & 3.0 \\
\hline
\end{tabular}

3.2The Process of Testing. According to the four mixes above, two sets of two individual sorts comparison specimen are made and cured under the need of specification with 26th days. One set of 
specimen are cured under standard specification, and another set of specimen are drawn from the curing box and put in oven at temperature of $(80 \pm 5)^{\circ} \mathrm{C}$ for $48 \mathrm{~h}$, after hot dried, and cooled in air-dried environment, then the one set of specimen are put into the box filled with solution of 5percent of $\mathrm{Na}_{2} \mathrm{SO}_{4}$ and soaked over $(15 \pm 0.5) \mathrm{h}$, during the period of this, $1 \mathrm{~N}$ of $\mathrm{H}_{2} \mathrm{SO}_{4}$ is dropped into the solution to neutralize $\mathrm{Ca}(\mathrm{OH})_{2}$, coming from the chemical reaction during the testing. And stired and kept the solution with $\mathrm{PH}$ at about 7.0, solution temperature at $(25 \sim 30){ }^{\circ} \mathrm{C}$. This soaking process is over, the solution is drained at once, and the specimen are air dried over $30 \mathrm{~min}$, then are made to keep temperature up to $80^{\circ} \mathrm{C}$ within $30 \mathrm{~min}$ in the box, and dried in temperature within ( 80 $\pm 5)^{\circ} \mathrm{C}^{[3]}$. This is a dry and wet cycle. The test has been keeping for three months, the results showed that the specimen with L-PC are obviously peeling off. Bad corrosion is showed.

\section{Analysis for Results of Tests}

The specimen made of only cement concrete without any admixture, which are under three months sulfate corrosion testing, are showed obviously phenomenon of peeling off, and there are some fine cracks on the surface of the specimen, corrosion is seriously. The anti-corrosion coefficient of compressive strength is only 42.2percent, this showed that the cement concrete is bad for sulfate corrosion; and the anti-corrosion coefficient of the cement concrete mixed with $15 \%$ fly ash instead the identity cement will be $55.8 \%$, better anti-corrosion for sulfate is showed. This solution has been illustrated on some essay, which said that the cement concrete mixed with some fly ash will increase the capability of concrete to anti-corrosion for sulfate ${ }^{[4]}$.

The capability of anti-corrosion will be increased with NS added in the cement concrete after mixed the fly ash replaced the identity cement, and more of NS adding, more capability to anti-corrosion. Where the content of NS reaches $0.5 \%$, the anti-corrosion coefficient will be $57.6 \%$, $15.4 \%$ increased, and where NS at $1.0 \%$, the coefficient be $60.4 \%, 18.2 \%$ increased, and where NS at $2.0 \%$, the coefficient be $65.7 \%, 23.5 \%$ increased, and NS at $3.0 \%$, the coefficient be $70.5 \%$, $28.3 \%$ increased. The results showed in table8 and figure1, figure 2.

Table5 the Coefficient of Concrete to Sulfate Corrosion (3Months)

\begin{tabular}{|c|c|c|c|c|}
\hline No. & $\begin{array}{c}\text { Strength Before } \\
(\mathbf{M P a})\end{array}$ & $\begin{array}{c}\text { Strength After } \\
(\mathbf{M P a})\end{array}$ & $\begin{array}{c}\text { The Coefficient to } \\
\text { Anti-Corrosion (\%) }\end{array}$ & $\begin{array}{c}\text { The Value } \\
\text { Increased (\%) }\end{array}$ \\
\hline L-1 & 61.3 & 25.9 & 42.2 & 0 \\
\hline L-2 & 60.2 & 33.6 & 55.8 & 13.6 \\
\hline L-3 & 62.3 & 35.9 & 57.6 & 15.4 \\
\hline L-4 & 64.5 & 39.0 & 60.4 & 18.2 \\
\hline L-5 & 70.4 & 46.3 & 65.7 & 23.5 \\
\hline L-6 & 62.8 & 44.3 & 70.5 & 28.3 \\
\hline
\end{tabular}

The concrete mixed with NS will improve the capability to sulfate resistance of concrete, the possible reason is that the scale of $\mathrm{Ca}(\mathrm{OH})_{2}$ can be reduced at the early time of cement paste hydrated, maybe the hydration happens the very early time of itself (such as the hydration happens while $\mathrm{C}_{3} \mathrm{~S}$ hydrates ), even when the $\mathrm{Ca}(\mathrm{OH})_{2}$ has not existed, some grout reacts with $\mathrm{Ca}^{2+} 、 \mathrm{OH}^{-}$etc. to produce calcium silicate hydrated, it avoids that $\mathrm{Ca}(\mathrm{OH})_{2}$ will be produced to make the structure defect. It has not proved about this image. Another reason maybe that the pores' structure of the cement concrete, which is mixed with NS, will be changed and improved, it is due to that the nano material, with the characteristic about particle and activity, will be able to fill and catalytic act and nucleatify. The density of cement concrete is increased. 


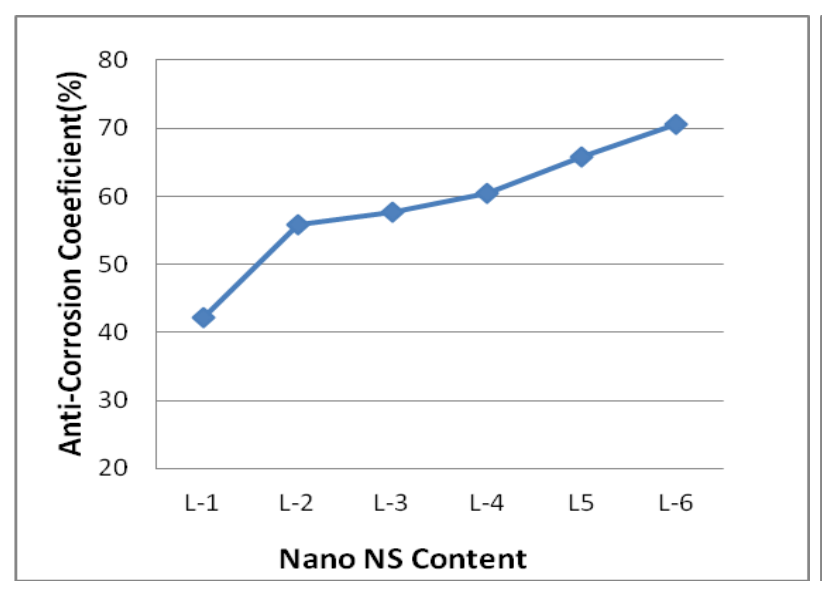

Figure1 The Testing Results of Pure Cement Concrete, With Fly Ash Replaced Identity CVement and NS as Admixture to Concrete With Fly Ash Above

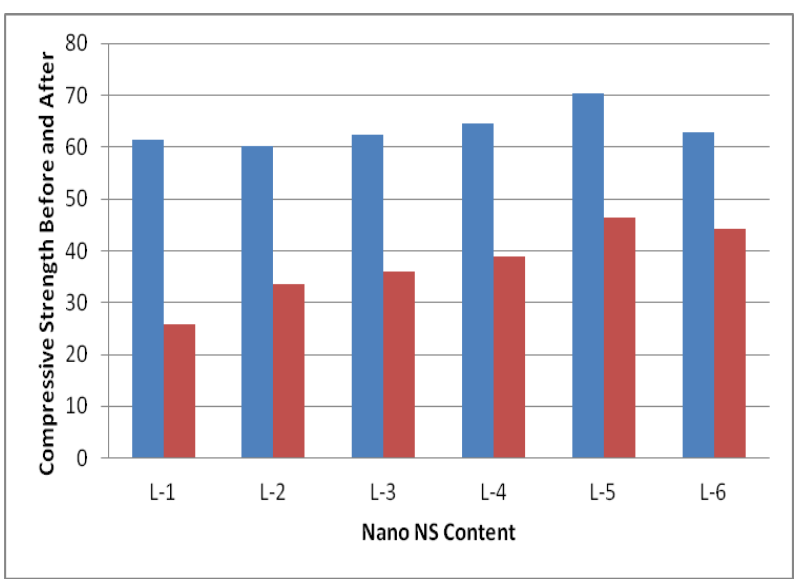

Figure2 Comparisons Between Compressive Strength Before and After

\section{Solution}

The tests showed that the capability of anti-corrosion to sulfate will increase with fly ash mixed in cement concrete, and the capability of this will increase more with NS as admixture. The cement concrete used in bridge building, which is explored in nature environment, will bear a lot of corrosion unknown, so the concrete may be considered some nano materials as admixture mixed into it as the mix of cement concrete is made.

\section{Acknowledgements}

Fund project: Key Techenology Project of Science And Technology To Longjian Road and Bridge Company Limited (LJKY008-2016)

\section{References}

[1] WANG Yuqian, CHENG Shoushan, Investigation and Analysis on Durability Index System of Domestic and Foreign Concrete Bridges, Journal of Highway and Transportation Research and Development , 2 (2012)

[2] Li Guhua, Effect of Nano Materials on Durability of Concrete. Southwest Jiaotong University, (2006)

[3] National Standard of The People's Republic of China. 《Standard for Test Methods of Long Term Performance and Durability of Ordinary Concrete》 (GB/T50082-2009) . Beijing: China Building Industry Press, 2009.

[4] Qing Honggeng, Pan Ganghua, Sun Wei etc., Study on Durability of High Performance Concrete With Fly Ash. China Concrete and Cement Products, 5 (2000) 